๑) Open Access Full Text Article

ERRATUM

\title{
Impact of an educational program on nursing students' caring and self-perception in intensive clinical training in Jordan [Retraction] [Erratum]
}

We have been advised that the retraction published in Advances in Medical Education and Practice 2014:5;157 contained an error. "Bayoumy HN" should be corrected to "Bayoumy HM".

Advances in Medical Education and Practice is an international, peerreviewed, open access journal that aims to present and publish research on Medical Education covering medical, dental, nursing and allied health care professional education. The journal covers undergraduate education, postgraduate training and continuing medical education including emerging trends and innovative models linking education, research, and health care services. The manuscript management system is completely online and includes a very quick and fair peer-review system. Visit http://www.dovepress.com/testimonials.php to read real quotes from published authors.

Submit your manuscript here: http://www.dovepress.com/advances-in-medical-education-and-practice-journal 